\title{
レーザーオリジナル
}

\section{遠赤外レーザー周波数測定のための掃引型 $\mathrm{FP}$ 干渉計}

\author{
桜井慧雄*・伊藤 信 彦*・石川 純*
}

\author{
（1982年12年20日，受理）
}

\section{A Scanning Fabry-Perot Interferometer for the Oscillation- Frequency Measurement of Far-Infrared Lasers Toshio SAKURAI, Nobuhiko ITO*and Jun ISHIKAWA*}

(Received December 20, 1982)

\begin{abstract}
A scanning Fabry-Perot interferometer with capacitive aluminium mesh mirrors, which can roughly estimate the oscillation frequency of far-infrared (FIR) laser for its direct frequency measurement, has been developed. The mesh-mirror separation is measured by using a visible laser interferometer (He-Ne $633 \mathrm{~nm}$ ) of frings counting type which is associated with the FIR interferometer. Using the Fabry-Perot interferometer, wavelengths of three FIR oscillation lines have been measured for evaluating its measurement error. It has been found that uncertatinties in the wavelength measurements are estimated to be less than $\pm 0.1 \mu \mathrm{m}$. This vale is smallenough to carry out the direct frequency measurement.
\end{abstract}

\section{1. はじめに}

近年，光励起遠赤外 (FIR) レーザー研究の 進展は目ざましい。年々新しい発振線が発見さ れ，その数は1500本を越えている ${ }^{1}$ 。応用研究の 展開もすばらしく, プラズマ診断, 天文学, 分子分光, ${ }^{3)}$ 長さ標準, 跳進が目につく。

いくつかの応用研究では, 光励起 FIRレーザ 一周波数を精密測定する必要がある。そして, 必要精度の最も高い分野が新しい長さ標準の研 究である。そこでは, 電磁波の波長 $\lambda$ が基準と なるが, $\lambda$ は, $c=\lambda \cdot \nu$ 関係式から求める。

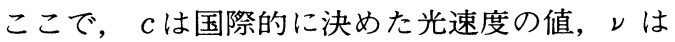
精度 $10^{-9}$ 以上で測定した, その電磁波の振動数
である。

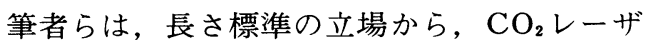
一の発振周波数を測定する周波数合成チェーン を提案してきた ${ }^{5,6)}$ 。そして, この中で, 光励起 $\mathrm{CH}_{3} \mathrm{OH}$ レーザー周波数の精密測定をおこなっ た。

FIRレーザー周波数の精密測定には，ミリ波 とFIR光の「周波数逓倍混合技術」を使う。 $\mathrm{FIR}$ 光の周波数 $f_{\mathrm{F} \mathrm{IR}}$ は, ミリ波の周波数 $f_{\mathrm{mm}}$ と中 間周波数 $f_{\mathrm{IF}}$ を用いて, $f_{\mathrm{F} \mathrm{IR}}=N \cdot f_{\mathrm{mm}} \pm f_{\mathrm{IF}}$ の関 係から求まる。ここで，Nは聥倍次数である。 $f_{\mathrm{mm}}$ は, 既成の技術で正確に周波数測定が可能 であり，また逓倍次数は，FIR光のおおよその 周波数があらかじめわかれば決まるから，FIR 光の精密周波数測定は, 中間周波 (IF) 信号の

*計量研究所（干 305 茨城県新治郡桜村梅園 1-1-4)

*'National Research Laboratory of Metrology (1-4, 1-Chome, Umezono, Sakura-Mura, Niihari-Gun, Ibaraki 305) 
周波数 $f_{\mathrm{IF}}$ の測定に帰着できる。 $f_{\mathrm{IF}}$ は, 通常, rf-スペクトラムアナライザで周波数測定する。 逓倍混合素子には, metal-insulator-metal (MIM). diode あるいはSchottky barrier diodeなどを使う。

あらかじめ知る FIR周波数の詳しさは，以下 に述べる状況から, IF周波数測定のしややすさに も密接に関連する。

（i ） IF 信号強度は, 通常 $10^{-11} \mathrm{~W}$ 以下である。 この程度の電力の観測では, rf-スペクトラムア ナライザの周波数掃引幅は狭く，また，掃引速 度を遅く選ばなければならない*ここで, FIR 周波数に大きな誤差が含まれれば，予想できる IF 周波数の範囲がその分だけ拡がるから, rfスペクトラムアナライザでIF信号を探すことに， いたずらに長い時間を費やすことになる。特に， MIMダイオードでは, ポストとホイスカーの機 械的接触（ダイオードの聥倍混合特性に直接影 響する）が不安定であるから ${ }^{7}, \mathrm{IF}$ 信号の探索に 長い時間がかかれば，実験はそれだけ難しくな る。

(ii)ここでの目的に使うダイオードは, 導波 管で供給するミリ波と, ビームで供給する FIR 光を混合するために，機械的構造は開放型であ

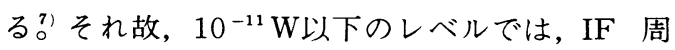
波数測定系に多くのノイズが混入する。外来ノ イズのスペクトラムは, 離散型と連続型が混合 したものであり,ノイズが分布する帯域は, 帯 域内の場所によって強弱はあるものの, rf- ス ペクトラムアナライザの全観測可能帯域におよ ぶ。この外来ノイズもIF信号の観測に大きな障 害である。*そのため, IF 周波数をできるだけ 正確に見積り，ミリ波の周波数を変えながら， IF信号をノイズの少ない周波数帯域で観測すれ ば，実験はそれだけ容易になる。

筆者らは, $251 \mu \mathrm{m} \mathrm{CH} \mathrm{CH}_{3} \mathrm{OH}$ レザー周波数を, あらかじめ $1 \mathrm{GHz}$ より良い精度で測定すること

*）これはrf-スペクトラムアナライザの動作原理 からの制約である。

**）ノイズを測定系からしゃ断する試みをおこなっ たが，困難であった。
を目標とした。これは, 主として, 使用する $\mathrm{rf}$ スペクトラムアナライザの動作周波数帯域から の制約である。

発振周波数をあらかじめ知るには, 発振波長 を測定し，光速度をその測定值で割る方法があ る。そして, その波長測定には, 出力同調曲線 の利用が簡便と思える。**しかし，筆者らの光

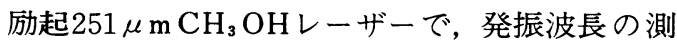
定精度は高々 $1 \mu \mathrm{m}$ であった。これは，251 $\mu \mathrm{m}$ 線の周波数に换算すると， $4 \mathrm{GHz}$ に当るから， 目標の精度にはおよばない。そこで, 測定精度 を高めるために，レーザー共振器外に置いて使 う $251 \mu \mathrm{m}$ 帯用掃引型ファブリペロ干涉計を試作 し，発振波長測定をおこなった。***

この干涉計は, $\mathrm{z}$ カット熔融石英板に capa-

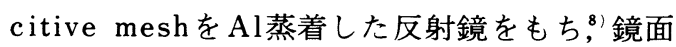
間隔の変化をフィゾー干渉計（光源は $\mathrm{He}-\mathrm{Ne}$ $633 \mathrm{~nm}$ レーザー）で読み取るものである。

本稿は, 試作した掃引型ファブリペロ干涉計 の構造, 動作, および光励起 $251 \mu \mathrm{m} \mathrm{CH} \mathrm{CH}_{3} \mathrm{OH}$ レーザーで発振する $163 \mu \mathrm{m}, 251 \mu \mathrm{m}, 469 \mu \mathrm{m}$ 線でおこなった波長測定精度の評価について述 ベる。

\section{2. 試作したファブリペロ干渉計}

\section{1 干渉計の構成}

試作したFIR帯用ファブリペロ干渉計の概念 困をFig. 1 に示す。この干渉計は, 反射鏡 $\mathrm{M}_{1}$, $\mathrm{M}_{2}$ で構成する FIRファブリペロ干渉計, 反射鏡 （無コーティングのオプティカルフラット） $\mathrm{M}_{3}$, $\mathrm{M}_{4}$ で構成する可視域フィゾー干渉計,のふたつ からなる。ここで, $\mathrm{M}_{1}$ と $\mathrm{M}_{3}$, および $\mathrm{M}_{2}$ と $\mathrm{M}_{4}$ は，それぞれ一体のホルダ $\mathrm{H}_{1}$ および $\mathrm{H}_{2}$ に格納 してあり, ホルダ $\mathrm{H}_{1}$ は固定, $\mathrm{H}_{2}$ は可動型とし て使う。後者の干涉計は, He-Ne633nmレー

***) FIRレーザー利得曲線幅は, 通常, 縦モード間 隔より狭いから, 出力同調曲線上では, 共振器長を 発振半波長だけ変えるごとに, 鋭い発振出力ピーク が観測できる。

****) $251 \mu \mathrm{m}$ 線は, Petersenらによって周波数が 精密測定されている(文献15)。しかし, この測定し か見当らないこと, また, 筆者らの線が, 彼らの線 と同一であることを確かめるためにおこなった。 


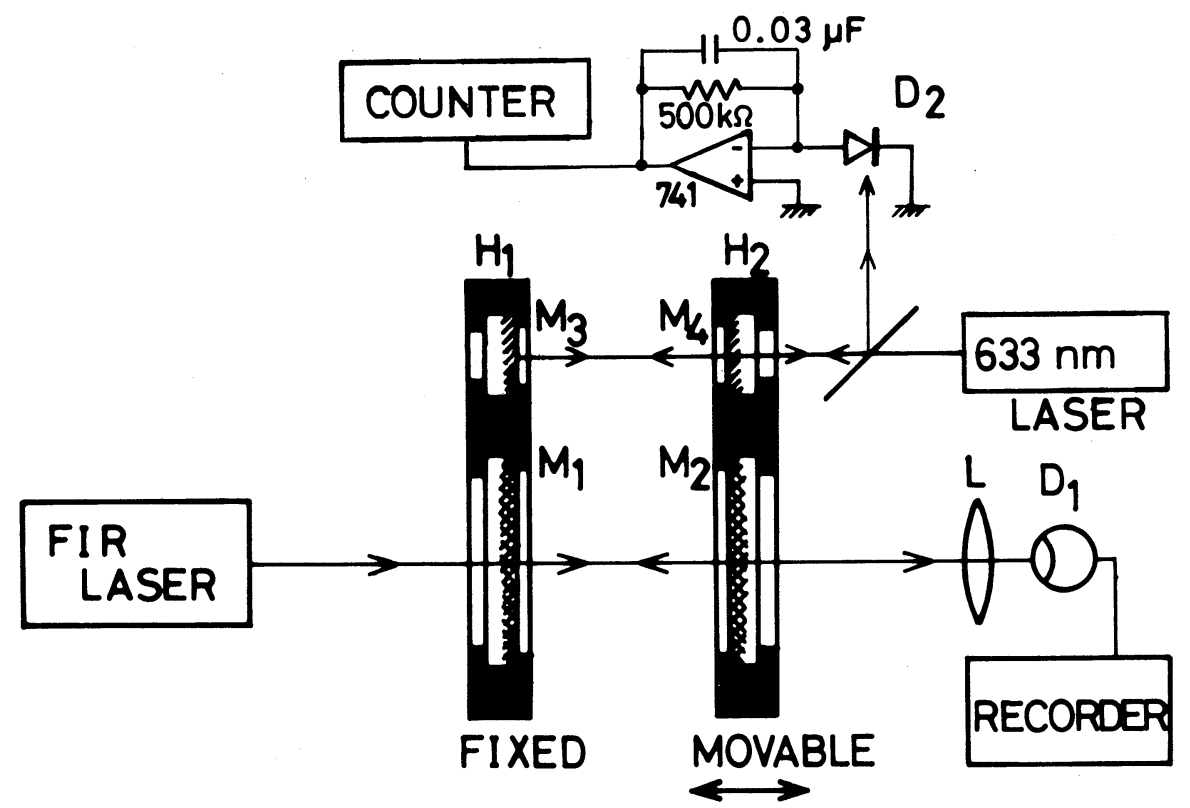

Fig. 1 Schematic of a Fabry-Perot interferometer for far-infrared wavelength measurements. $M_{1}$ and $M_{2}$, capacitive aluminium-mesh mirrors with a z-cut crystal quartz substrate; $M_{3}$ and $M_{4}$, glass optical flats; $H_{1}$ and $\mathrm{H}_{2}$, mirror holders; L, TPX lens with a focal length of $100 \mathrm{~mm} ; D_{1}$, pyroelectric sensor; $\mathrm{D}_{2}, \mathrm{Si}$-photodetector. This interferometer consists of FIR $\left(M_{1}\right.$ and $\left.M_{2}\right)$ and visible $\left(M_{3}\right.$ and $\left.M_{4}\right)$ interferometers. $\mathrm{H}_{2}$ is movable and is placed on a linear-translation-stage which runs on ballbearlng rails. The movable section of the stage is $200 \times 100 \mathrm{~mm}^{2}$ wide. The displacement of $\mathrm{H}_{2}$ is measured by the visible interferometer counting the interference fringe.

ザーを光源とし, ホルダ $\mathrm{H}_{2}$ の移動量を, 干渉縞 の計数で測定するものである。

$\mathrm{H}_{2}$ は, 可動部が長さ $200 \mathrm{~mm}$, 幅 $100 \mathrm{~mm}$ のボール ステージに塔載し, 差動マイクロメータ（みつ とよ $\left.\mathrm{MHF}_{2}-2.5 \mathrm{~V}\right)$ で平行移動できる。マイク ロメータの駆動は, 減速ギヤ付小型直流モータ でおこなう。両者の間に緩衝材は使用していな い。振動などの影響による干渉縞のミスカウン トを防ぐために, 干渉信号の増幅器には, ロー パスフィル夕特性 $(-3 \mathrm{~dB}: 10 \mathrm{~Hz}, 6 \mathrm{~dB} / \mathrm{oct})$ を持たせてある。

\subsection{FIR 帯用反射鏡}

ファブリペロ干渉計では，高い反射率をもつ 鏡が必要である。FIR 帯での高反射率鏡は, Ulrichが研究した金属メッシュ鏡およびワイヤ
グリッド鏡,9) Danielewiczが開発した MMD鏡, Wolfeのcapacitive mesh鏡,11) などがある。こ こでは, 有効径 $38 \mathrm{~mm} の$ Wolfe 型 capacitive mesh鏡を使用した。これは, $\mathrm{z}$ カット結晶水晶

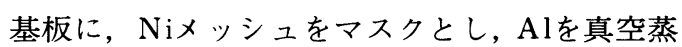
着したものである。 2 枚の鏡は同一規格のもの で, 約 $30 \mathrm{~mm}$ 間隔で置き, ファブリペロ干渉計と して使う。メッシュは, 格子定数が $102 \mu \mathrm{m}$, リ ボン幅が30 $\mu \mathrm{m}$ のもを用いた。

$\mathrm{z}$ カット結晶水晶は, 可視および遠赤外 $(\lambda>$ $50 \mu \mathrm{m})$ で透明な材料であるから, $\mathrm{He}-\mathrm{Ne} 633 \mathrm{~nm}$ レーザーが鏡の平行度調整に使える。使用した 基板の平面度は可視光で 3 縞, 平行度は 1 分で ある。

\section{3 可動鏡の平行移動持性}


可動鏡の微動送りでの最大移動量は, $2.5 \mathrm{~mm}$ である。可動鏡の平行移動特性を，最小目盛10 秒のオートコリメータで調べた。その結果，移 動による平行度のくるいは認められなかった。 平行移動は等速でおこない, その速度は, 約 0.1 $\mathrm{mm} / \mathrm{min}$ である。

\section{4 干渉計の調整}

ファブリペロ干渉計の 2 枚の鏡 $\mathrm{M}_{1}, \mathrm{M}_{2}$ は,

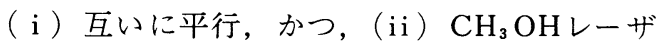
一光軸に垂直におき，（iii）鏡の中心に $\mathrm{CH}_{3} \mathrm{OH}$ レーザーの光軸を通す必要がある。これらを実 行するために，市販の内部鏡型 $\mathrm{He}-\mathrm{Ne} 633 \mathrm{~nm}$ レーザーを利用した。

まず，He-Ne633nmレーザーを， $\mathrm{CH}_{3} \mathrm{OH} レ$ 一ザーの出力空より約 $1 \mathrm{~m}$ 離して向き合わせて

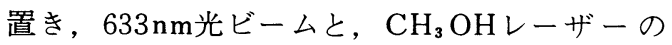
光軸を一致させる。この調整ができたらば，う ブリペロ干渉計を両レーザーの中間点におき， 633 nm光ビームが, capacitive mesh鏡の中心 を通るように，干渉計の位置を目測で調整する。 この段階で， 2 枚の capacitive mesh鏡からは， 肉眼で見てほぼ同一光量の十文字状の回折光が $\mathrm{He}-\mathrm{Ne} レ$ ザー側に反射してくる。この回折光 をFig. 2 に示す。次に, 十文字の交点の輝度は

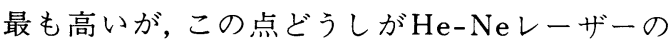
出射口近傍で重なるように鏡の傾きを合わせ込 む。可動鏡をゆっくりと掃引すれば，十文字の の交点が見やすいので, 平行度の調整が容易に なる。その後, 干渉計全体を微少回転し, 十文 字の交点を完全に $\mathrm{He}-\mathrm{Ne} レ$ ザーの光軸上に 返す。ここまでの作業で, 鏡の垂線と $\mathrm{CH}_{3} \mathrm{OH}$ 一ザー光軸とは, $90^{\circ} \pm 3^{\prime}$ 以内に調整される。

平行度のさらに細かい調整は, FIR光の透過 光強度曲線の形を見ておこなう。 2 枚の鏡のな す角を $\alpha$, 約 $30 \mathrm{~mm}$ ある鏡面間隔での干渉次数を $m$ とした時, $m \alpha^{2}{ }^{2}$ が充分小さければ，得られる 透過光強度曲線が最大強度点に対して対称であ り,フィネスは最大になるから"2, このことを利 用して平行度をさらに良くできる。

Fig. 3 は, 平行度調整が完了したファブリペ

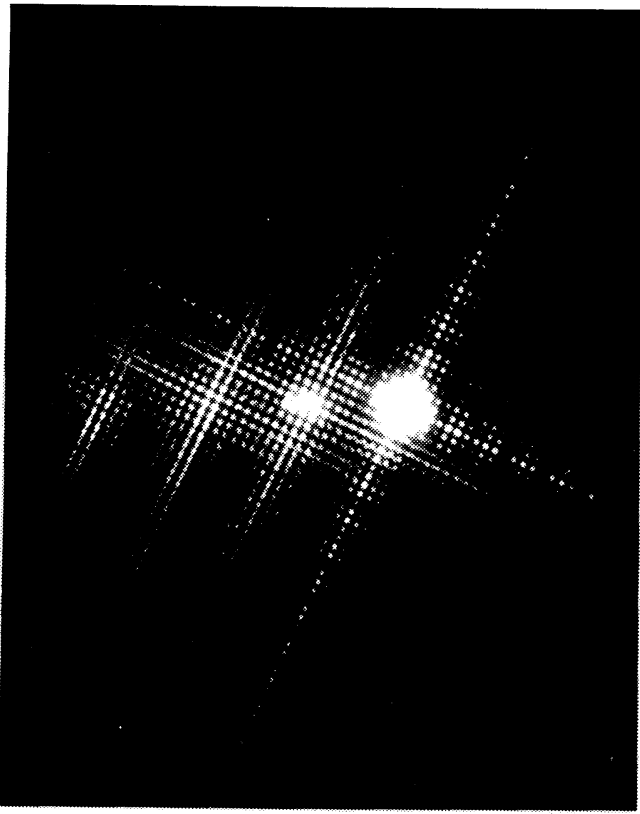

Fig. 2 Photograph of reflected He-Ne $633 \mathrm{~nm}$ laser beam from the capacitive aluminiummesh mirrors of Fabry-Perot interferometer when the two mirrors are adjusted nearly parallel.

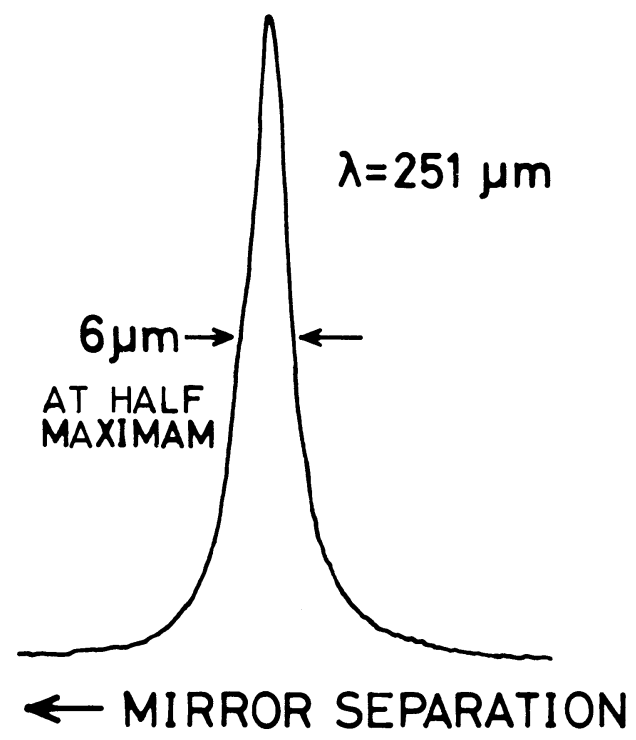

Fig. 3 Transmission profile of the Fabry-Perot interferometer obtained by using the 251 $\mu \mathrm{m}$ radiation after the adjustment of parallelism is finished. The finess and the reflectivity at $251 \mu \mathrm{m}$ are measured to be 21 and $86 \%$, respectively. 
ロ干渉計で得た $251 \mu \mathrm{m}$ 線の透過光強度曲線であ る。フィネスは 21 , 曲線の対称性からの平行度 は30秒以内である。

フィネスヨが充分高いファブリペロ干渉計で, ヨは，関係式 $=\pi \sqrt{R /(1-R)}$ によって,メッ

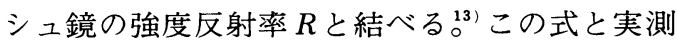
したフィネスから，3本の線でのメッシュ鏡の 強度反射率は， $163 \mu \mathrm{m}$ 線で $74 \%, 251 \mu \mathrm{m}$ 線で $86 \% ， 469 \mu \mathrm{m}$ 線で $64 \%$ を得た。 Capacitive meshの強度反射率は, Ulrich の理論9) では,

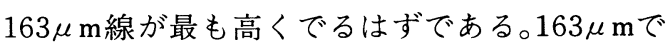
での強度反射率が $251 \mu \mathrm{m}$ 線より低い原因は，(i) $163 \mu \mathrm{m}$ 線が理論の成立限界 $g / \lambda \leq 0.7$ に近いた め, 理論の精度が悪くなったこと, あるいは, (ii) 基板のファブリペロエタロン効果による。 ここで， gは格子定数，入は入射波長である。

金属メッシュの理論では, $g / \lambda \leq 0.7$ なば, メッシュは光学的に等方特性をもつ反透明鏡で ある听用いた 3 本の線は，いずれもこの条件を 満たす。しかし，Fig. 3 で示した左右対称な透 過曲線は，メッシュ鏡のリボンの向きが同一方 向の時にのみしか得られなかった。この原因は, 使用したメッシュ鏡の異方性（蒸着したメッシ 工の画素の形状が，鏡面上の場所によって多少 異る）に起因すると考えるが, 現在, 究明中で ある。

フィゾー干渉計の鏡 $\mathrm{M}_{3}, \mathrm{M}_{4}$ は, capacitive $\operatorname{mesh}$ 鏡 $M_{1}, M_{2}$ とは独立したネジで平行度の調 整ができる。 $\mathrm{M}_{3}, \mathrm{M}_{4}$ の調整は， $\mathrm{M}_{1}, \mathrm{M}_{2}$ の調整 が完了後, $633 \mathrm{~nm}$ 干渉縞が全面同一の干渉次数 になるように傾きを調整する。

\section{3. 光励起 $251 \mu \mathrm{m} \quad \mathrm{CH}_{3} \mathrm{OH}$ OHーザー}

FIR用ファブリペロ干渉計の精度評価には， 筆者のひとりが試作した光励起 $251 \mu \mathrm{m} \mathrm{CH} \mathrm{CH}_{3} \mathrm{OH}$ レーザーを用いた。FIR共振器長は2.1m, 内径

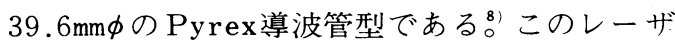
一は，25Wの $\mathrm{CO}_{2}$ レーザー10R (38) 線励起で, $163 \mu \mathrm{m}, 251 \mu \mathrm{m}, 469 \mu \mathrm{m}$ 線が, それぞれ, $34 \mathrm{~mW}$, $18 \mathrm{~mW}, 8 \mathrm{~mW}$ の $\mathrm{EH}_{11}$ モードで発振する。干渉 計の精度評価をおこなう時には, 各線の出力
が，上記出力のおおよそ $1 / 3$ である。出力モー ドは $\mathrm{EH}_{11}$ である。また， 発振周波数を手動で FIR線のline centerに同調し, 波長測定をおこ なう。

\section{4 . 波長測定法}

波長測定は次のようにおこなう。Fig. 1 にお いて, まず, 可動鏡に0.1 $\mathrm{mm} / \mathrm{min}$ で等速送りを かける。それによって, フォトダイオード $\mathrm{D}_{2}$ では, $633 \mathrm{~nm}$ 干渉縞信号が約 $5 \mathrm{~Hz}$ で検出され る。また, 焦電検出器 $\mathrm{D}_{1}$ では, FIR光の干渉縞 信号を受ける。

可視光干渉縞カウンタのゲートは, FIR光の 透過光強度が，その干涉次数での最大值の $1 / 2$ に

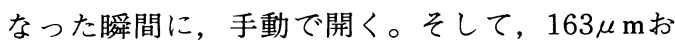

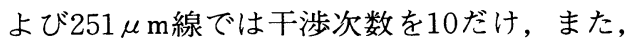
$469 \mu \mathrm{m}$ 線では 5 だけ変えた次数での FIR干渉縞 の強度が，その次数での最大透過光強度の $1 / 2 に$ なった瞬間に, 手動でカウンタのゲートを閉じ る。 $1 / 2$ 強度点を干渉縞計数の基準点にした理由 は, その点では, 可動鏡の位置変化に対する F IR干渉縞強度の変化率が, 最大值に近いから, 可動鏡の位置決めに正確さを期せるためである。

こうして求めたカウンタの読みに, 0.316412 $\mu \mathrm{m}\left(633 \mathrm{~nm}\right.$ 光の $20^{\circ} \mathrm{C}, 1$ 気圧での半波長) をか ければ，10山測定*ではFIR光で 5 波長， 5 山 測定ではFIR光で 2.5 波長に相当する可動鏡の 移動距離が求まる。

\section{5. 波長測定結果}

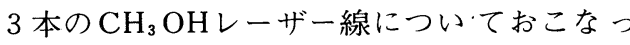
た波長測定結果をTable Iにまとめる。また, Table II は, Table Iを周波数で表現した表で ある。Measured wavelengthおよびfrequency は,いずれも, line centerの值である。Table I から，10山測定10回の平均で，3本の線の標 準偏差が約 $0.1 \mu \mathrm{m}$ であることがわかる。ただし， $469 \mu \mathrm{m}$ では, 標準偏差の值を $\sqrt{2}$ で割って考え た。

*) FIR光干渉次数を10次分だけ変えるように可動鏡 を掃引する測定。 


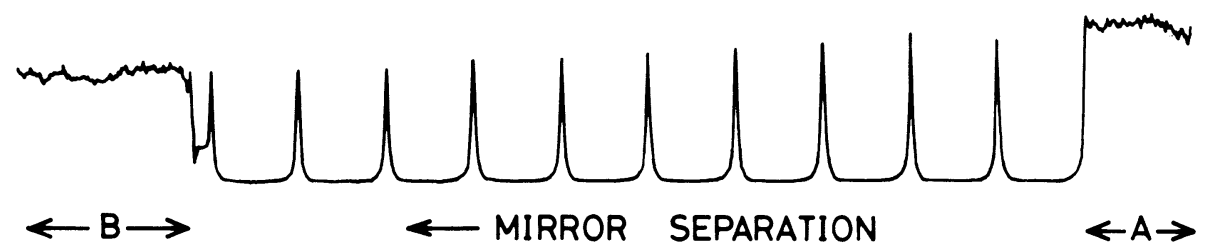

Fig. 4 Typical interferogram of the Fabry-Perot interferometer obtained by using the $251 \mu \mathrm{m}$ radiation. The movable mirror is translated by a distance of ten transmission peaks.

Table I. Summary of the wavelength measurements.

\begin{tabular}{llll}
\hline $\begin{array}{l}\text { Wavelength } \\
(\mu \mathrm{m})\end{array}$ & $\begin{array}{l}\text { Red fringe } \\
\text { count }\end{array}$ & $\begin{array}{c}\text { Measured } \\
\text { wavelength } \\
(\mu \mathrm{m})\end{array}$ & $\begin{array}{c}\text { Standard } \\
\text { deviation } \\
(\mu \mathrm{m})\end{array}$ \\
\hline 163 & $2575.9 \pm 1.2$ & 163.01 & 0.076 \\
251 & $3968.2 \pm 1.1$ & 251.14 & 0.070 \\
469 & $3705.8 \pm 1.5$ & 469.02 & 0.190 \\
\hline
\end{tabular}

a) Each figure is an avarage of ten readings and its standard deviation. Each reading is taken when a FIR mirror is translated by ten-transmission $=$ peak distance in the $163 \mu \mathrm{m}$ and $251 \mu \mathrm{m}$ lines, and five-transmission-peak in the $469 \mu \mathrm{m}$ line, respectively.

b) Calculated with a red wavelength of $0.6328844 \mu \mathrm{m}$ in air.

Table II. Evaluation of the wavelength measurements in the frequency domain.

\begin{tabular}{cccc}
\hline $\begin{array}{c}\text { wave length } \\
(\mu \mathrm{m})\end{array}$ & $\begin{array}{c}\text { Frequency } \\
(\text { GHz) }\end{array}$ & $\begin{array}{c}\text { Uncertainty } \\
( \pm \mathrm{EGZ})\end{array}$ & $\begin{array}{c}\text { Frequency }{ }^{\mathrm{a}} \\
\text { difference } \\
(\mathrm{GHZ})\end{array}$ \\
\hline 163 & 1839.11 & 0.88 & 0.27 \\
251 & 1193.82 & 0.32 & 0.09 \\
469 & 639.19 & 0.26 & 0.01 \\
\hline \hline
\end{tabular}

a) Frequenby difference between the frequency converted frow the wavelength, and the directly measured frequency. See Ref. 15.

Table II でfrequencyは, 光速度 $299,792,458$ $\mathrm{m} / \mathrm{s}$, Table I $の$ measured wavelength で割った值である。Uncertaintyは，Table I のstandard deviationを周波数に変換したもの である。Frequency difference.は，第 2 行目

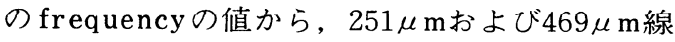
で桜井らがおこなった精密周波数測定の值, ${ }^{14)}$ または，3本の線について Petersen らがおこ なった測定の值, ${ }^{15)}$ を差し引いた值である。

Table IIから, $251 \mu \mathrm{m}$ おび $469 \mu \mathrm{m}$ につい
Table III. Summary of measurement errors.

\begin{tabular}{lc}
\hline \hline Accidental error & $\begin{array}{c}\text { Uncertainty } \\
( \pm \mu m)\end{array}$ \\
\hline 1. Positioning in the FIR fringe & \\
Mannual start/stop for red fringe counting & 0.01 \\
FIR output fluctuation & $0.04^{b}$ \\
2. \pm I count error & 0.03 \\
3. Mechanical vibration & \\
4. Fluctuation of the refractive indexes of air $c$ & $\sim 0.04$ \\
5. Thermal expantion of the interferometer & \\
6. Fluctuation of wavelengths ${ }^{c}$ & $\sim 0$ \\
\hline Systematic error & \\
\hline 1. Correction for the refractive indexes of air $c$ & $0.07^{d}$ \\
2. Back-talk from the interferometer & $\sim 0$ \\
3. Axis-alignment between the FIR laser and & $\sim 0$ \\
the interferometer & $\sim 0$ \\
4. Divergence of laser beams ${ }^{c}$ & $\sim 0$ \\
\hline \hline
\end{tabular}

a) Uncertainty included in each measured wavelength. It is estimated for the ten-transmission-peak measurement of FIR fringe.

b) Estimation at $251 \mu \mathrm{m}$ where finess $=20$, and FIR output flubtuation $=10 \%$ of the avaraged output.

c) Including both contributions in the visible and FIR regions.

d) Extrapolation by the Edlén's formula.

ては, uncertaintyおよびfrequency difference とも, 目標に選んだ $1 \mathrm{GHz}$ より 小さい值を示す ことがわかる。163 $\mu \mathrm{m}$ 線のuncertainty が大き い理由のひとつは, 他の線に比して波長が短い いのにもかかわらず，他の線とほぼ同じstandard deviationをもつためである。（Table I 参照)。ボールステージのストロークは $2.5 \mathrm{~mm}$ るから, $163 \mu \mathrm{m}$ 線に対しては, 干渉次数の変化 が10次より多い測定をおこなうことで, standard deviationを小さくできる。

Fig. 4 に，251 $\mu$ m線でおこなった干渉縞の 10 山掃引での時間送りチャートレコーダの記録を 示す。横軸は鏡面間隔, 縦軸は透過光強度であ 


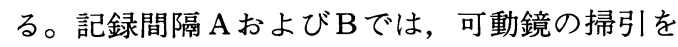
止めてあるから, 短周期 $(1 \sim 5 \mathrm{~s})$ の出力変 動の大きさが, 全出力の10～15\%あることがわ かる。

\section{6. 測定誤差の分析}

Table III は, 俁差要因の一覧表である。表 は, 干渉次数変化が10次であるFIR干渉縞を観 測した時に，推定できる誤差を見積ってある。

偶然誤差では, FIR出力の出力変動によるば らつきが最も大きい。この值は, $251 \mu \mathrm{m}$ 線での 干渉計の代表的特性 (finess $=20$, output fluctuation=10\%）で見積ってあるが, finessが 小さく，あるいはfluctuationが大きくなると, この値はそれだけ悪くなる。

手動操作による $633 \mathrm{~nm}$ 干渉縞の計数誤差は, オシロスコープと低周波発振器によるシュミレ ーションから推定した。

第 $1 ， 2$ 項に示した偶然誤差の自乗和の平方 根は0.05 $\mu \mathrm{m}$ とる。この值を, Table Iに示 した $251 \mu \mathrm{m}$ 線の standard deviation $0.07 \mu \mathrm{m}$ と比較すれば，約 $0.04 \mu \mathrm{m}$ の偶然譜差が第 $3 \sim 5$ 項に示す原因から発生しているはずである。こ れに関して, 筆者らは, 第 3 項の効果が大きい と考える。しかし, 正確には, 干渉計のモー夕 駆動にクッションを介する実験をおこない, そ の結果との比較対照が必要である。

$633 \mathrm{~nm}$ 光およびFIR光の波長ゆらぎは, 大き くても $10^{-7}$ の桁であるから, 他の偶然誤差に比 ベ無視できる。

系統誤差の中で, 空気屈折率の問題は, 物理

*) 例えば, $251 \mu \mathrm{m}$ 干渉縞をひと山記録する時間は, おおよそ $10 \mathrm{~s}$ である。まず, 低周波発振器で周期 $10 \mathrm{~s}$ の正弦波を発生させ, これを, 横軸の掃引を止めたオ シロスコープの縦軸に入力し, 振幅 $6 \mathrm{~cm}$ の輝点の単振 動を観測する。FIR干渉縞の $1 / 2$ 強度点はチャートレコ ーダ上で観測するが，オッシロスコープの輝点の振幅 は，チャートレコーダ上の記録寸法とほぼ同じである。 輝点がブラウン管の中点を通過する瞬間にカウンタの ゲートを開け，1 $\mathrm{ms}$ のパルスクロックを計数する。 輝点が再び中点を通過する瞬間に手動でゲートを閉じ る。この操作を 20 回反復し, ブラウン管の中点から中 点までの時間間隔のばらつきを求め, 波長測定での手 動操作の影響を推定した。
的に興味深い。可視光での Edlênの空気屈折率 補間式は, $3 \mu \mathrm{m}$ の赤外線でも成立することが 確かめられたが16) それ以上長い波長での報告は 見当らない。Table IIIに示した量は, Edlénの 標準空気屈折率の式に, 便宜上, FIR線波長の 值を代入したものである。

FIR 領域では, 水蒸気などの吸収による異常 分散のため, 屈折率が急変する波長の存在が予 想できる。坂井の吸収係数測定の結果 ${ }^{17)}$ を参考 にすると, $163 \mu \mathrm{m}, 251 \mu \mathrm{m}, 469 \mu \mathrm{m}$ では, 吸収 のピークは見当らないが, 目標とする波長測定 精度によっては, 吸収ピークの裾の屈折率への 影響を考慮する必要があろう。しかし, 結論と して, Table IIIに示した偶然誤差で 3 つの波長 を測定する限り, 空気屈折率の補正は, 測定精 精度に決定的な影響をおよぼさない。

バックトークは, FIRレーザーの発振波長に 影響するが, その影響は, FIR共振器長が発振 半波長変わるごとに, 周期的に反復するので, ここでの波長測定值には影響がないと考えた。 また, 光軸のアラインメントのくるい $\alpha$ は余弦 誤差を生じ, 測定值は, $1-\alpha^{2} / 2$ 倍の変化を受 けるが， $\alpha \leq 10^{-3}$ (約 $3^{\prime}$ ) であるから，その影 響は小さい。回折拡がりによる誤差は, 伊藤の 誤差解析を参考にして算出したが, ${ }^{18)}$ 無視できる 量である。

\section{7. 結論}

光励起FIRレーザー周波数を精密測定する準 備として, その周波数をあらかじめ $1 \mathrm{GHz}$ 良い精度で測定するFIR 帯用ファブリペロ干渉 計を試作した。そして，その性能を評価するた めに, 3 本の光励起 $\mathrm{CH}_{3} \mathrm{OH}$ レーザー線で波長 測定をおこない, 光速度 $c$ との割算から, おお よその発振周波数を求めた。その結果, 測定し た発振周波数のばらつき, その平均值の精密測 定値からの偏差，のいずれもが $1 \mathrm{GHz}$ より良い 精度を示すことがわかった。ただし，163 $\mu$ m線 については, 2.0山〜30山測定が必要であろう。

測定誤差の分析結果は, FIR光の出力変動, および, \pm 1 カウント誤差による偶然誤差が, 
大きい比重をしめることを示した。さらに測定 精度を向上するためには，本報告でおこなった 掃引をさらに長い掃引にすれば良い。しかし，

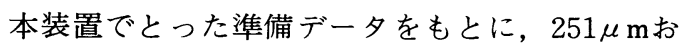
よび $469 \mu \mathrm{m}$ 線について周波数の精密測定ができ たことは，その目的に対しては，本装置が精度 的に充分な性能を持つといえる。

\section{8. 謝辞}

ファブリペロ干渉計の機械的設計に対し，有 益な助言をいただいた計量研究所第一部光学計 測課長清野昭一氏に感謝する。

\section{参考 文 献}

1) 山中：応用物理 49 (1980) 813.

2 ) 例えば, 西沢, 野田, 藤田, 山中, 武田, 岡島, 牧 野, 長坂, 小泉, 籍崎, 高井, 村上, 長島, 綱脇, 近, 近藤, 仲田: 核融合研究 45 (1981) 476 .

3) 例えば, J. O. Henningsen: IEEE J. Quantum Electron. QE-13 (1977) 435.

4) 例えば, D. J. E. Knight, G. J. Edwards, P. R.
Pearce, and N. R. Cross: IEEE Trans. Instrum. Meas. IM-29 (1980) 257.

5 ) 田中, 桜井, 伊藤, 黒沢, 盛永, 岩崎 : 第 42 回応物 学会予稿集 (1981秋) p. 190.

6 ) K. Tanaka, T. Sakura i, N. Ito, T. Kurosawa, A. Morinaga, and S. Iwaski: Proc. Precision Measurement and Fundamental Constants II, June 1981, NBS Gaithersburg.

7 ) 黒沢, 田中, 桜井：レーザー研究 9 (1981) 547.

8 ) 桜井：レーザー研究 10 (1981)

9 ) R. Ulrich: Infrared Phys. 7 (1967) 37.

10) E. J. Danielewicz and P. D. Coleman: Appl. Opt. 15 (1976) 761.

11) S. M. Wolfe, K. J. Button, J. Waldman, and D. R. Cohn: Appl. Opt. 15 (1976) 2645.

12）豊田，桜井：計量研究所報告 20 (197, 23 .

13) M. Born and E. Wolf: Principles of Optics (4-th Ed.), Pergamon Press (London, 1970) p. 328 .

14) T. Sakurai, T. Kurosawa, and A. Morinaga: to be published.

15) F. R. Petersen, K. M. Evenson, D. A. Jennings, J.S. Wells, K. Goto, and J. J. Jiménez: IEEE. J. Quantum Electron. QE-11 (1975) 838.

16) H. Matsumoto: Metrologia 18 (1982) 49.

17) K. Sakai: Appl. Opt. 11 (1972) 2894.

18）伊藤：計量研究所報告 28 (1979) 63. 